30. Viiskovosluzhbovtsi LYTPOLUKRBRYH u Liublini rozpochaly pershe spilne navchannia «Brave Band». [Online]. Available from: http://www.mil.gov.ua/news/2016/02/01/vijskovosluzhbovczilitpolukrbrig-u-lyublini-rozpochali-pershe-spilne-navchannya-brave-band [Accessed: 18 th July 2018].

31. "Ukroboronprom" u 2017 rotsi: spivpratsia z NATO ta spilni rozrobky.[Online]. Available from: http://ukroboronprom.com.ua/uk/media/ukroboronprom-u-2017-rotsi-spivpratsya-z-nato-ta-spilnirozrobky.html [Accessed: 18 th July 2018].

Надійшла до редколегії 18.05.2018

Godliuk Alona, $\mathrm{PhD}$ in Political Science, the State Institution "The Institute of the World History of the National Academy of Sciences of Ukraine", Kyiv, Ukraine

\title{
NATO AND EU POSITIONS ON UKRAINE'S INTEGRATION TO EUROPEAN AND EURO-ATLANTIC STRUCTURES IN THE CONTEXT OF THE CRISIS OF EUROPEAN SECURITY
}

\begin{abstract}
The article examines situation of the European security system and the main challenges that appears in the second half of 2010, in particular, the impact of the Syrian crisis and Russian aggression against Ukraine. Author investigated the main changes of the European security strategy; also examined the main areas of cooperation with the EU and NATO and proposed options for Ukraine's cooperation with the European and Euro-Atlantic structures in order to provide adequate responses to the security threats on the European continent.

Furthermore, author notes that Ukraine will remain in the center of the European security agenda for a long time. European leaders and the civil society are aware of the clear link between the Russian-Ukrainian conflict and the threats to the national security of the EU countries and try to pursue the most balanced policy so that they do not exacerbate the conflict with the Russian Federation.

Conclusions are as follow: Due to the current situation, it is vital for Ukraine to strengthen cooperation with the EU and NATO countries, because this significantly improve the chances of integration into European and Euro-Atlantic structures in future. Therefore, the deeper and longer will be confrontation between Russia and the West, the more chances for Ukraine to change the skepticism of the European elites toward their own European prospects.
\end{abstract}

Key words: NATO, EU, crisis of the European security system, Ukrainian crisis, European security strategy, European integration.

\section{УДК. 327.8}

http://doi.org/10.17721/2521-1706.2018.05.197-206

\author{
Natalia Yakovenko, \\ professor, \\ Institute of International Relations, \\ Taras Shevchenko National University of Kyiv \\ Galyna Piskorska, \\ Senior Researcher, \\ Institute of International Relations, \\ Taras Shevchenko National University of Kyiv
}

\section{TRANSFORMATION OF NATO PUBLIC DIPLOMACY}

Abstract. The article deals with key principles and practical assignments in the field ofNATO public diplomacy, evolution of NATO public diplomacy during a period from the end of cold war to contemporary time, determinationof factors, exerting influence on aims, tasks and priorities of strategic communicative efforts of the Alliance in the modern world, analysis of adaptation of basic principles of public diplomacy to the realities of globalization.The writers 
stress that the policy of public diplomacy conducted by the North Atlantic Alliance is a very effective political instrument.In the post-bipolar period, there was a profound transformation of the architecture of NATO public diplomacy bodies.Particular attention was paid to deepening the work of public diplomacy in the post-Soviet space.It is mentioned in the article that on the territory of former Soviet republics a wide network of NATO public diplomacy structures has been deployed - NATO information offices, communications missions. The most widely structures of NATO public diplomacyare represented in Ukraine. One of the most vivid examples ofeffectiveness of these structures is the activities of NATO Information and Documentation Centerwhich has been successfully working to improve understanding and awareness about NATO's among Ukrainian citizens for over twenty years. Analysis of the evolution of NATO's public diplomacy in the post-bipolar period demonstrates the high potential of adapting its functions, goals and objectives to the current strategic guidance of the North Atlantic Alliance.

Key words: NATO's Public Diplomacy; threats and challenges; NATO Information and Documentation Center.

Under current conditions, public diplomacy becomes an important structural component of strategy of leading actors in world politics, to which the North Atlantic Treaty Organization (NATO) belongs. Against the background of significant changes in recent years, the strategy and organizational structure of the Alliance,its various forms and methods of influence in foreign policy to create the own positive image, becamea topical problem of research among Ukrainian and foreign scholars.

In most research papers, public diplomacy and strategic communications go hand in hand with each other.Thus, the subject of our article is considered as a component of strategic communications, in particular, in the work of the London Center Chatham House P. Cornish, J. Lindlie-French, C. Yorke [1, p. 6].Concerning Ukrainian research of this topic, it is worth first of all mentioning the work of G. Pocheptsov, dealing with strategic communications in business, politics and public administration [2]. As the writer notes, political, economic and military victories are being fought not only in the physical space, but also in the minds of people. Without the support of public opinion development is impossible. At the same time, a newer view can be found in A. Barovska's article "Strategic Communications: NATO Experience" [3].

Academic understanding of public diplomacy is, first of all, interpersonal contacts within the framework of educational programs, scientific and cultural exchanges, as well as in an open political dialogue. In general, the main tools of public diplomacy are joint public events (visits, seminars, conferences, press conferences, public debates, various projects, research, publications, radio, television, film production, etc.), designed to convey the necessary information about the organization to the world community. According to the practice of NATO military missions, support of the local population, the population of the country as a whole and the international community is critical for the resolution of the conflict [4]. A new phenomenon, denoting contemporary conflicts, is the interconnection between different target audiences. As a result of emergence of new media, cultural awareness has increased and at the same time, the differentiation between these groups has deepened, which, however, is the common global audience.

In defining key principles and directions of practical work in the field of NATO public diplomacy, it should be noted that the policy of public diplomacy conducted by the North Atlantic Alliance is a very effective instrument that enables achieving the goals set in the field of foreign policy activities of the bloc.The end of the Cold War has put NATO civilian diplomacy to face the need of solving previously untapped tasks.In 1991 and 1999, NATO Strategic Concepts were adopted, which were based on the political and 
military strategic guidelines of the "flexible response" strategy, complemented by the changed military-political situation after the end of the Cold War. Their implementation took place against the background of Russia's extreme weakening of the economic and military potential and strengthening the position of the United States as the only superpower.

Under these circumstances, the most important task was to justify, for both internal and external entities, the need to preserve the Alliance in the absence of the former Soviet threat, as well as the need for NATO further expansion [5-7].At the same time, significant efforts of public diplomacy were aimed at supporting and clarifying key initiatives in the framework of the partnership network that was formed: the EuroAtlantic Partnership Council (EAPC), the Partnership for Peace (PfP) and other new Alliance initiatives: the Mediterranean Dialogue, the Istanbul Initiative Cooperation, Initiatives for South-Eastern Europe [8; 9].The Alliance's public diplomacy was tasked with creating a positive image of NATO, explaining to governments and public figures in the countries of the region the essence and purpose of each of the initiatives to change the identity of the elites in favor of Euro-Atlanticism.In parallel, the efforts of public diplomacy were aimed at harmonizing views on key issues such as NATO transformation, peacekeeping and crisis management. Everything was emphasized on non-military aspects of the Alliance's activities.An important focus was to facilitate the coordination of diplomatic efforts between NATO, the EU and the OSCE, and to justify NATO's role in peacekeeping and humanitarian support.

As part of the events in the Balkans, NATO's public diplomacy solved the task of clarifying the Alliance's goals in the region outside of the traditional zone of responsibility of the organization. The central point of the 1999 Strategic Concept was the declaration by the alliance of the right to conduct military operations outside the territory of NATO member states. The right to conduct such operations stemmed from the concept of a new vision of the North Atlantic Treaty Organization as a guarantor of international security in a global dimension [7].

The massive terrorist act of September 11, 2001, launched a "period of new security conditions" and put a number of tasks for the Alliance's public diplomacy concerning active involvement of new NATO allies and partners, including the Caucasus and Central Asia, into its sphere of influence.Additional diplomatic steps were taken to deepen NATO's interaction with international organizations, primarily with the UN, the European Union and the OSCE.A marked practical focus was given to the events held under the aegis of the NATO-Russia Council.An important sector of NATO's public diplomacy was formed when, under the UN mandate, the Alliance in August 2003 headed the mission of the International Security Assistance Force in Afghanistan (ISAF) [10].

A new impetus to public diplomacy measures to cover and support the transformation of the military capabilities of the bloc was given bythe "Prague Capabilities Commitment" taken at the Prague Summit (2002).Similarly, the decisions of further NATO summits influenced the development of the three basic foundations of the Alliance: operations and missions, military potential and partnerships [11, 12].

At the heart of the 2010 Strategic Concept "Active Engagement, Modern Defence" there are political and military-strategic settings of previous doctrinal documents, taking into account changes in the military-political situation associated with terrorist attacks in the United States, the wars in Afghanistan and Iraq, "colored revolutions"in a number of countries [13]. The target setting is the foundation for the formation of a global military- 
political organization based on NATO. At the same time, the strategy of "nuclear deterrence", adapted to new conditions, continues to be one of the key elements of US and NATO policy.

The withdrawal of NATO contingent from Afghanistan in 2014 objectively leads to a gradual shift of this country and its public diplomacy to the periphery of the Alliance's interests.However, the North Atlantic bloc directs public diplomacy to active actions throughout the "crisis arc", the length of which the Alliance determines from the Sahel (between the Sahara and Sudan) to Central Asia.Such an ambition will require allies to maintain and improve the full spectrum of capabilities, including missile defense, cyber defense of the force of special operations, and enhanced partnership.In the activities of public diplomacy, the main attention was given to supporting the development plans of the NATO component of EuroAMD, improving the capabilities of the NATO Response Force, and conducting large-scale exercises. The complex of activities underway marks a peculiar shift in the strategy of public diplomacy from the information tasks of the NATO-involved in conflict settlement to the tasks of NATO ready for operations ("transition from a deployed NATO to a prepared NATO") [14]. In 2014, the North Atlantic Alliance suspended all practical cooperation with Russia in response to its aggressive actions in Ukraine.This cooperation included projects in Afghanistan, antiterrorism projects and scientific cooperation.Projects have eventually achieved results, but their suspension did not undermine the security of the North Atlantic Alliance or the ability to withstand such contemporary challenges as terrorism.

In a concentrated form, the strategy of NATO public diplomacy development in the current context is presented in "Public Diplomacy Strategy" [15], the document of the Alliance's Public Diplomacy Committee.The document outlines two main priorities of public diplomacy: to demonstrate the role and achievements of NATO in operations and missions (mainly in Afghanistan and the Balkans), as well as the new identity of the Alliance and strategic directions for its development in hardly predictable environment.The target groups in NATO countries and partner countries have been identified: political leaders, parliamentarians, security researchers and experts, journalists, teachers, scientists, heads of authoritative non-governmental organizations (NGOs) and especially young people.Recommendations for maximizing the potential of all modern means of communication are included.

The Strategy is based on the general principles of public diplomacy, which were formulated in 2003 by the Advisor to the US State Department on Public Diplomacy C. Ross [16]. They include the following:

- the first responsibility must always be to ensure that foreign audiences understand US policies for what they are, not for what others say they are;

- to ensure that information priorities are clear, overall themes are established, messages are consistent, and resources are used effectively;

deeper understanding and broader dialogue with states and peoples;

to remain rooted in the fundamental values and culture of the United States;

all public messages can, and will, reach multiple publics;

to employ vastly different images and words for different audiences;

to conduct audience research that is as frequent and in-depth as resources permit;

- the strength of international alliances and private-sector partners, whether global corporations, humanitarian organizations, or US ex-patriot communities abroad; 
to take the best of the United States to other countries, to offer who we are and what we stand for, sharing with them our contributions in representative government, science, technology, literature, the arts, and English teaching;

exchanges are inestimable in demonstrating the ideas of freedom, optimism, and sense of future possibilities that make the United States so compelling to the world.

According to C. Ross, "By adhering to the principles embodied in the seven pillars of public diplomacy, the United States can advance not only its national interests, but the universal values of freedom, equality, and opportunity that we share with the world" [16].

According to Russian experts, the principles formulated by the American are fully used by NATO public diplomacy [17]. Main attention is paid to reorientation to solution of new tasks: crisis management; peacekeeping and dialogue with non-NATO memberstates. Concerning specifics of NATO, recommendations for adaptation of public diplomacy mechanisms and impact on target groups are as follows:

in practical work, to focus on reduction of NATO military activities, including reduction of the number of armed forces with the transition of some of them to a reduced level of combat readiness;

- to emphasize the reduction of the role of the nuclear component in the military strategy;

to reluctantly demonstrate the development of the Alliance's non-military functions through the implementation of a political course aimed at security through the development of dialogue and cooperation;

to explain and justify the new missions of the Alliance that go beyond the functions defined by the North Atlantic Treaty.

Flexible and operative adaptation of the plan of operations of public diplomacy to the difficult foreseeable changesof external and internal conditions is envisaged in order to achieve the goal with the necessary efficiency.The purpose of the management, methods and means of its achievement, the intensity of their use, as well as the objects of applied efforts arechanging. Situation monitoring and feedback should provide management structures with data analysis and prediction of a political situation, which increases the effectiveness of the public diplomacy operation.

In the post-bipolar period, there was a profound transformation of the architecture of NATO public diplomacy bodies. Traditionally, the problem of choosing methods and finding means for fulfilment the task of informing its public about the policy and objectives of the North Atlantic Alliance is decided by every member state on its own.In the early 1990s, the role of the NATO Information and Print Bureau was to complement actions on public and leadership awareness through daily media communications with the Alliance [18].Today, in addition to NATO itself, a number of national and international bodies deal with public diplomacy: the embassies of NATO and EAPC countries, national parliaments and the North Atlantic Assembly, national Atlantic councils, committees or Atlantic associations, institutes and foundations, public information offices at NATO headquarters, educational and North Atlantic Alliance Educational Institutions and National Institutions of Education, as well as the Atlantic Treaty Association, the Alliance Confederation of Reserve Officers [19].

Since the early 2000s, NATO's Public Diplomacy Division, whose functions have been substantially expanded, began to operate at NATO Headquarters in Brussels, in particular by informing the public about a wide range of scientific and environmental programs. The goals of the "Security through Science" Program were to promote security, stability and solidarity through the use of science potential, as well as support for 
democratic reforms in NATO partner states through the establishment of large-scale scientific collaboration, computer networks support and grants [10]. The potential of the Program was actively used to study the situation, the targeted impact on the students and scientific community of partner countries, research on topics of interest to NATO.Due to NATO grants, regular public opinion sensitization was conducted to coordinate efforts to create a positive image of NATO [20].

NATO's current activities of public diplomacy include NATO-funded programs that consist of activities held at the Headquarters in Brussels, external events held by NATO staff, activities under the aegis of governmental or non-governmental organizations outside NATO Headquarters, which NATO can support on a conceptual, practical or financial level, as well as activities organized by other external institutions with direct or indirect support from NATO.

Particular attention is paid to deepening the work of public diplomacy in the postSoviet space.The main task here is to establish channels of bilateral strategic communication between NATO and the states, to create a positive and attractive image of the North Atlantic Treaty Organization among various groups of the population: the ruling elites, business communities, creative intelligentsia, military, youth. The ultimate goal is to change the identity of the elites in favor of Euro-Atlanticism.The potential of NATO's public diplomacy was significantly increased in the field of communication and information, focusing on three main areas: press and media, external interaction, dissemination of information in electronic and printed form. "NATO-TV" channel was created, strong headquarters information website, information sites of the local information offices and offices of the Alliance in the EAPC countries, including all CIS and CSTO states are actively functioning, print and video products are widely distributed.

Today, a large network of Alliance's Public Diplomacy structures - NATO Information Offices, communications missions - has been deployed on the territory of the former Soviet republics.NGOs funded by the West closely interact with them.The most extensive structures of NATO and Western public diplomacy are represented in Ukraine, where for many years work has been conducted at the level of leaders and the general public.For twenty years, the NATO Information and Documentation Center in Ukraine has been working to improve understanding and awareness about NATO's among Ukrainian citizens.During this time, according to the Director of the NATO Information and Documentation Center in Kyiv, Barbora Maronkova, the Center has organized more than two hundred study visits and visits for students, journalists, scientists, and parliamentarians to the NATO Headquarters in Brussels. In April 2017, a trip to Brussels was held for the winners of the "Games of Heroes" competition held in Ukraine. This visit was particularly symbolic, as some of the participants will compete in the Ukrainian national team at the "Games of the Non-Conquered", which will be held later in Toronto this year. One of NATO's trust funds helped cover travel expenses of the team's trip to Toronto. This is a concrete example of support, emphasizes B. Maronkova, which NATO provides to Ukraine in the framework of the Alliance's public diplomacy."We actively supported many non-governmental organizations during the Revolution of Dignity, including the Ukrainian Crisis Media Center, in order to provide the world with actual information and news on the events in certain places. We rendered financial assistance ordinary activists who fought against Russian propaganda, and we helped to create new independent Ukrainian media.The Center also actively supports the Ukrainian government in creating effective strategic and anti-crisis communications.For twenty years of its active work in Ukraine, the NATO Information and Documentation 
Center has made an important contribution to Ukraine.The theme of NATO is no longer a taboo, and many myths and stereotypes about NATO are scattered through an active dialogue" [21].

In Ukraineare also functioning: the NATO-Ukraine Liaison Office, the EuroAtlantic Cooperation Institute, the NATO-Ukraine Inter-Parliamentary Council, the Institute of the Transformation of Society (ITS) with its own network holding, containing 53 information resources, the NATO-Ukraine Public League and others. Social networks have fundamentally changed the capabilities of public diplomacy. They allowed to increase the audience of information users in tens, hundreds of times.

A vivid example of the use of new opportunities were the events of the first decade of the XXI century in the states of the Middle East and North Africa. Until the wellknown events of September 11, due to a number of circumstances, the countries of this region were not considered to be a priority in public diplomacy of the United States and NATO members.The 2001 terrorist attacks forced the US political leadership to reconsider such an attitude.The large-scale Project "Middle East Initiative Partnership", which has united over three hundred fifty programs in the field of education, culture and democracy, has mobilized huge financial resources [22]. During 2002-2009, the number of Arab population, who studied in the United States and participated at home in the US government programs, increased significantly. Particular attention was paid to the involvement of young people and women in the political life.

The network of non-governmental organizations that became centers of uniting citizens standing for democratization of political regimes has quickly succeeded. A similar system of implementation of this method was used in Ukraine as well. The Head of NATO Communications Services Division of Public Diplomacy Steven Menger said in March 2015: "In Eastern Europe, demand for our products has grown" [23].

Thus, the analysis of the evolution of NATO's public diplomacy in the post-bipolar era demonstrates the high potential of adaptation its functions, goals and objectives to the strategic directions of the North Atlantic Alliance.Today, NATO is actively using public diplomacy technologies in all areas. The Alliance's experts carry out many research and analytical works, monitor national and international surveys to better represent the picture of the processes taking place in the world.NATO actively uses intensive forms of propagandist activities to present itself as a transparent and interactive object.The Alliance has broad links with the press and other media.The organization successfully uses social media and communication tools. Much attention is paid to social media and new digital technologies. The offensive nature of NATO's public diplomacy in today's somewhat chaotic world is determined by the severity of contradictions between individual states and the Alliance.This factor makes public diplomacy an important tool for influencing international relations, politics, dialogue between parties with inadequate national interests, as well as those whose task is to establish and conduct such a dialogue - diplomats, politicians, military, mass media.Public diplomacy is an effective tool, since it provides an opportunity to influence those who, in democratic societies, decide the future of their state: people who choose certain power.Thus, it is possible to interact with the authorities of another country, not only directly but also indirectly, forming the necessary issues in the public discourse of foreign society.

\section{Sources}

1. Cornish P. Strategic Communications and National Strategy [Електронний ресурс] / P. Cornish, J. Lindley-French, C. Yorke // A Chatham House Report. - September 2011. - P. 6. - Режим доступу : https://www.chathamhouse.org/publications/papers/view/178465 
2. Почепцов Г.Г. Стратегические коммуникации: стратегические коммуникации в политике, бизнесе и государственном управлении / Г. Г. Почепцов. - К. : Альтерпрес, 2008. -216 с.

3. Баровська А.В. Стратегічні комунікації: досвід НАТО / А. В. Баровська // Стратегічні пріоритети. - 2015. - № 1 (34). - С. 147-151.

4. Активне залучення, сучасна оборона. Стратегічна концепція оборони та безпеки членів Організації Північноатлантичного договору, прийнята главами держав та урядів у Лісабоні 19 листопада 2010 року [Електронний pecypc]. - Режим доступу: http://www.nato.int/ nato_static/assets/pdf/pdf_publications/20120214_strategic-concept-2010-ukr.pdf.

5. О расширении НАТО [Електронный ресурс]. - Режим доступа: http://nato.weurope.org/show.php?art=104\&rubr=33 (дата обращения: 15.07.2016).

6. Стратегическая концепция НАТО, Рим, 7-8 ноября1991 г. [Електронный ресурс]. - Режим доступа: http://www.nato.int/ (дата обращения: 15.07.2016)

7. Стратегические концепции НАТО [Электронный ресурс]. - Режим доступа: http://www.nato.int/cps/ru/natolive/topics_56626.htm (дата обращения: 6.02.2017).

8. Партнерство ради мира: Рамочный документ, Брюссель, 10 января 1994 года. [Электронный pecypc]. - Режим доступа: URL: http://arhiv.inpravo.ru/data/base281/text281v304i987.htm (дата обращения: 19.02.2014)

9. НАТО-Украина. Новые не афишируемые реалии [Электронный ресурс]. - Режим доступа: URL.: $\quad$ http://gubkin.info/politics/84379-nato-ukraina-novye-neafishiruemye-realii.html (дата обращения: 15.02.2014).

10. Справочник НАТО. Управление общественной дипломатии НАТО.- Брюссель, 2006. $440 \mathrm{c}$.

11. Пражский саммит и преобразование НАТО. Справочник-путеводитель. Управление общественной дипломатии НАТО. - Брюссель, 2003. - 118 с.

12. Стамбульский саммит. Справочник-путеводитель. Управление общественной дипломатии НАТО. - Брюссель, 2004. - 156 с.

13. 2010-2011 NATO Public diplomacy strategy. [Електронний ресурс]. - Режим доступу: http://publicintelligence.net/nato-public-diplomacy-2011/ (дата звернення: 25.02.2017).

14. Closing the gap: Keeping NATO strong in an era of austerity. Speech by Ambassador Alexander Vershbow, NATO Deputy Secretary General at the 48th Annual Security Conference of the Norwegian Atlantic Committee, Oslo, Norway, 11 Feb. 2013. [Електронний ресурс]. - Режим доступу:URL: http://www.nato.int/cps/en/ 2C102202/natolive/opinions_98350.htm?selectedLocale=en (датазвернення: 09.01.2017).

15. 2010-2011 NATO Public diplomacy strategy. [Електронний ресурс]. - Режим доступу:http://publicintelligence.net/nato-public-diplomacy-2011/ (дата звернення: 25.02.2017).

16. Ross C. Pillars of Public Diplomacy / Christopher Ross [Електронний ресурс]. - Режим доступу:URL.:

https://www.google.ru/\#newwindow=1\&q=christopher+ross+pillars+of+public+diplomacy (датазвернення: 15.02.2017).

17. Рогозин А.Д. Общественная дипломатия НАТО и угрозы информационной безопасности России / А. Д. Рогозин // Власть. - 2008. - Сентябрь. - С. 26-32.

18. Справочник НАТО. Партнерство и сотрудничество. Бюро информации и печати НАТО. 1995. $-368 \mathrm{c}$.

19. Справочник НАТО, издание к 50-летию НАТО.Отдел информации и прессы, 1998-1999 гг. $-406 \mathrm{c}$.

20. Социологическое исследование «Россияне о НАТО». Информационное бюро НАТО, октябрь 2013 г. [Электронный ресурс]. - Режим доступа:URL.: http://nato.w-europe.org/archive.php. (дата обращения: 15.02.2014)

21. Маронкова Б., директор Центра информации и документации НАТО в Киеве. Акцент на «мягкой силе»: Почему публичная дипломатия НАТО имеет важное значение для Украины? Електронний ресурс]. - Режим доступу: https://day.kyiv.ua/ru/article/den-planety/akcent-na-myagkoysile

22. Цветкова Н.А. Публичная дипломатия США и революции в арабском мире/ Н. А. Цветкова / [Электронный pecypc]. - Режим доступа: http://mir-politika.ru/237-publichnayadiplomatiya-ssha-irevolyucii-v-arabskom-mire.html. (дата обращения: 02.09.2012). 
23. НАТО открыло в Риге штаб для информационной войны в Восточной Европе [Электронный ресурс]. - Режим доступа: http://bb.vesti.lv/politika/item/9162088-nato-otkrylo-vrigeshtab-dlya-informatsionnoj-vojny-v-vostochnoj-evrope (дата обращения: 29.03.2015).

\section{References}

1. CORNISH, P., LINDLEY-FRENCH, J. and YORKE, C. Strategic Communications and National StrategyinA Chatham House Report, September 2011.[Online]. Availablefrom: https://www.chathamhouse.org/publications/papers/view/178465 [Accessed: 15th December 2017].

2.POCHEPTSOV, G. G. (2008) Strategicheskiye kommunikatsii: strategicheskiye kommunikatsii v politike, biznese i gosudarstvennom upravlenii.Kyiv: Alterpres.

3.Barovska, A.V.(2015) Stratehichni komunikatsiyi: dosvid NATO. Stratehichni priorytety.1 (34). p. $147-151$.

4. Active Engagement, Modern Defence. Strategic Concept for the Defence and Security of the Members of the North Atlantic Treaty organization. Adopted by Heads of State and Government at the NATO Summit in Lisbon 19-20 November 2010. [Online]. Available from: http://www.nato.int/ nato_static/assets/pdf/pdf_publications/20120214_strategic-concept-2010-ukr.pdf. $15^{\text {th }}$ December 2017].
5. O rasshyrenyy
NATO
[Online].
Available from:
http://nato.weurope.org/show.php?art=104\&rubr=33 [Accessed: $15^{\text {th }}$ December 2017].

6. NATO Strategic Concept, Rome, November 7-8, 1991[Online]. Available from: http://www.nato.int/ [Accessed: February 15 2017].
7. Strategicheskiye
kontseptsii
NATO
[Online].
Available
from: http://www.nato.int/cps/ru/natolive/topics_56626.htm [Accessed: 02nd February 2017].

8. Partnership for Peace: Framework Document, Brussels, 10 January 1994. [Online]. Available from: URL: http://arhiv.inpravo.ru/data/base281/text281v304i987.htm [Accessed: 19th February 2017].

9. NATO-Ukraina. Novyye ne afishiruyemyye realii [Online]. Available from: URL.: http://gubkin.info/politics/84379-nato-ukraina-novye-neafishiruemye-realii.html [Accessed: 15th February 2017].

10. NATO Handbook. NATO Public Diplomacy Division (2006).Brussels. 440 p.

11.Prazhskiy sammiti preobrazovaniye NATO. Spravochnik-putevoditel'. Upravleniye obshchestvennoy diplomatii NATO (2003). Brussels.118 p.

12. Stambul'skiy sammit. Spravochnik-putevoditel'. Upravleniye obshchestvennoy diplomatii NATO (2004). Brussels. 156 p.

13. 2010-2011 NATO Public diplomacy strategy. [Online]. Available from: http://publicintelligence.net/nato-public-diplomacy-2011/ [Accessed: $25^{\text {th }}$ February 2017].

14. Closing the gap: Keeping NATO strong in an era of austerity. Speech by Ambassador Alexander Vershbow, NATO Deputy Secretary General at the 48th Annual Security Conference of the Norwegian Atlantic Committee, Oslo, Norway, 11 Feb. 2013. [Online]. Available from:URL: http://www.nato.int/cps/en/ SID-21281BCB-2C102202/natolive/opinions_98350.htm?selectedLocale=en

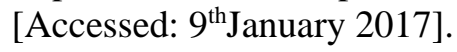

15. 2010-2011 NATO Public Diplomacy Strategy. [Online]. Available from:http://publicintelligence.net/nato-public-diplomacy-2011/ [Accessed: $25^{\text {th }}$ February 2017].

16. ROSS, C. Pillars of Public Diplomacy[Online].Available from:

https://www.google.ru/\#newwindow=1\&q=christopher+ross+pillars+of+public+diplomacy[Access ed: $25^{\text {th }}$ February 2017].

17. Rogozin, A. D. (2008) Obshchestvennaya diplomatiya NATO i ugrozy informatsionnoy bezopasnosti Rossii. Vlast'. September. p. 26-32.

18. NATO Handbook. Partnership and Cooperation. NATO Information and Press Bureau (1995).368 p.

19. NATO Handbook, publication for the 50th anniversary of NATO. Information and Press Bureau (1998-1999). 406 p.

20. Sotsiologicheskoye issledovaniye "Rossiyane o NATO". Informatsionnoye byuro NATO (oktyabr' 2013) [Online]. Available from:URL.: http://nato.w-europe.org/archive.php. [Accessed: 15th February 2014].

21. MARONKOVA, B. (2017) Aktsent na 'myagkoy sile': Pochemu publichnaya diplomatiya NATO imeyet vazhnoye znacheniye dlya Ukrainy [Online]. Available from: https://day.kyiv.ua/ru/article/den-planety/akcent-na-myagkoy-sile[Accessed: 9th March 2017]. 
22. TSVETKOVA, N.A. (2012) Publichnaya diplomatiya SSHA i revolyutsii v arabskom mire [Online]. Available from: http://mir-politika.ru/237-publichnaya-diplomatiya-ssha-irevolyucii-varabskom-mire.html. [Accesed: 2 nd September 2012].

23. NATO otkrylo v Rige shtab dlya informatsionnoy voyny v Vostochnoy Yevrope [Online]. Available from: http://bb.vesti.lv/politika/item/9162088-nato-otkrylo-v-rigeshtab-dlya-informatsionnojvojny-v-vostochnoj-evrope [Accessed: 29th March 2015].

Надійшла до редколегії 10.10.2018

Яковенко Наталя Леонідівна, доктор історичних наук, професор кафедри міжнародних організацій і дипломатичної служби IМВ КНУ імені Тараса Шевченка, Київ.

Піскорська Галина Андріївна, кандидат історичних наук, доцент, старший науковий співробітник IМВ КНУ імені Тараса Шевченка, Київ.

\section{ТРАНСФОРМАЦІЯ ПУБЛІЧНОЇ ДИПЛОМАТІї ПІВНІЧНОАТЛАНТИЧНОГО АЛЬЯНСУ}

Анотація. В статті розглянуто ключові принциипи і напрями практичної роботи у сфері публічної дипломатії НАТО, еволюиію публічної дипломатії НАТО впродовж періоду від закінчення холодної війни до теперішнього часу, визначено чинники, щзо впливають на цілі, завдання і пріоритети стратегічних комунікативних зусиль Альянсу у сучасному світі, аналізується адаптація базових принщипів громадської дипломатії до реалій глобалізащії.Зазначено, щуо на території колишніх радянських республік розгорнута велика мережа структур публічної дипломатії Альянсу - інформачійних бюро НАТО, місій зв'язку. Найбільш широко структури громадської дипломатії НАТО представлені в Україні. Показовим прикладом ефективності иих структур є діяльність Центру інформачії та документачії НАТО, який впродовж понад двадияти років успішно працює з метою поліпшення розуміння і інформованості про НАТО серед українських громадян. Центр також активно підтримує украӥнський уряд в створенні ефективних стратегічних і антикризових комунікацій. Аналіз еволючії публічної дипломатії НАТО в постбіполярну епоху свідчить про високий потенціал адаптації ї̈ функиій, иілей $і$ завдань до сучасних стратегічних настанов Північноатлантичного альянсу.

Ключові слова: публічна дипломатія НАТО, загрози та виклики, фактори, иілі, завдання, пріоритети, базові принщипи, Центр інформаџіï та документаџії НАТО в Україні. 